\title{
Analysis of the Influence of Fulfillment, Responsiveness, Website Design, Privacy on Loyalty through Trust and Satisfaction on Tokopedia Customers in Surabaya
}

\author{
Sukristiawan Joel Bolo, Ronald ${ }^{\mathrm{b}}$, Amelia $^{\mathrm{c} *}$ \\ ajoelbolo8@gmail.com \\ ${ }^{a}$ Master of Management Student at Pelita Harapan University, Surabaya 60234, Indonesia \\ ${ }^{b, c}$ The Lecturer of Master of Management at Pelita Harapan University, Surabaya 60234, Indonesia
}

\begin{abstract}
Along with the technological developments and the high flow of globalization, it has had a tremendous impact on human in all over the world. The development of information technology has caused the role of telecommunications to be very necessary as a support for the convenience of the community in carrying out activities. One of the positive impacts of technological developments is the internet. The internet indirectly has a major influence on the development of science and world views. PT Tokopedia is one of the companies that engaged in the technology industry, where PT Tokopedia provides online selling applications with the aim of improving the nation's economy.

This research is purposed to analyze the influence of several variable as Fulfillment, Responsiveness, Website Design, Privacy, Trust, Satisfaction, on Loyalty. In increasing the positive impact on Loyalty, the sample that is used in this research are the Tokopedia's customers aged between 18-60 years' old that have installed the Tokopedia application online, both male and female domiciled in Surabaya that have reached the Tokopedia help center and have made transactions on Tokopedia for at least 2 times in the last two months. This research has had used 110 respondents and Amos 22.0 to process data.
\end{abstract}

Key Words: Fulfillment, Responsiveness, Website Design, Privacy, Trust, Satisfaction, Loyalty.

\section{Introduction}

Along with the development of high technology and globalization, bringing tremendous impact for many people in the world. In it, there is a fast exchange of information, so that countries can be connected and open to one another. The development of information technology is increasingly fast, causing the role of telecommunications to be very important as a support for the convenience of the community in carrying out activities. One of the positive impacts of technological development is the internet. The internet indirectly has a major influence on the development of science and world views. Only by using the Internet, users can get various kinds of information that is very complete when compared to looking for information in library books. (www.kompasiana.com downloaded on 25 May 2020).

In the last five years from 2015, the number of internet users in the world experienced significant growth. According to We Are Social and Hootsuite data, the population of the earth connected to the internet in 2018 reached four billion compared to 2014 which only reached 2.4 billion people. This figure shows the level of internet penetration which has reached $52.96 \%$ of the world's total population of 7.59 billion people. As for the number of internet users in Indonesia, Indonesia has been named the largest in 2018 in Southeast Asia. This was revealed in research conducted by Google and Temasek under the title 'e-Conomy SEA 2018'. According to this research, in 2018 the total internet users in the Southeast Asia region were 350 million. And of these, 150 million of them are from Indonesia, which is said to be the country with the most internet users in Southeast Asia (www.kumparan.com, downloaded on May 25, 2020).

In the retail industry, the development of the internet is very influential and influential for existing business users. Starting from small industry movers and even extending to the retail industry which is quite large, so that some people create an application that makes it easy for consumers to use it and can quickly get what they are looking for. The platform that combines retail and online is called a marketplace. According to Opiida, 2014 Marketplace is defined as an internet-based (web-based) online medium where business activities and transactions between buyers and sellers are conducted. In its use, the marketplace must be packaged attractively and consider several aspects such as design, security, ease of use and so on. One of the marketplaces that consumers often use is Tokopedia. (www.pend Pendidikan.co.id downloaded on 25 May 2020).

Tokopedia is an online-based application, with the aim of bringing together sellers and buyers on the same online platform. As can be seen in Figure 1.1 which is an image of the official Tokopedia logo, which was founded by William Tanuwijaya and Leontinus Alpha Edison on August 17, 2009. Tokopedia was founded with the aim of digital economic equity. Tokopedia allows individuals and business owners in Indonesia to open and manage their online store easily and free of cost, while providing a safe and comfortable online buying and selling experience. The hard work and efforts made by Tokopedia were successful and yielded sweet fruit by winning the Best Company in Customer Industry award at the 2016 Indonesia Digital Economy Award held by MarkPlus Inc. (www.ekonomi.bisnis.com downloaded on May 25, 2020). 
This research discusses the factors that influence loyalty. To see the factors that influence loyalty based on several replicated and compiled journals, we will examine whether Fulfillment, Responsiveness, Website Design, and Privacy have a positive influence on Loyalty through Trust and Satisfaction on Tokopedia users in Surabaya.

\section{Litterature Review}

\subsection{Theories and Hypotheses}

\subsubsection{Fulfillment to Trust}

Singh and Sirdershmukh (2000) say that Fulfillment has a significant effect on Trust, because in this case Trust concerns the idea of capability in terms of including fulfillment (fulfillment) of a promised service in an honest and reliable manner. In the research of Al-Dweeri et al. (2018) found that Fulfillment has a positive effect on Trust. And according to Kim et al. (2009) which in their research revealed that Fulfillment has a positive and significant effect on Trust.

\section{Hypothesis 1: Fulfillment has a positive and significant effect on the Trust.}

\subsubsection{Responsiveness to Trust}

Giovanis, A. N., \& Athanasopoulou, P. (2014) revealed that Responsiveness has a positive and significant effect on trust. Sur, S. (2015) stated that Responsiveness has a positive and significant influence on trust. Responsiveness also affects trust, this is because customers want to be responded to quickly and this is beneficial for customers (Konradt et al., 2003).

\section{Hypothesis 2: Responsiveness has a positive and significant effect on the Trust.}

\subsubsection{Webstite Design to Trust}

Sur, S. (2015) stated that Website Design has a positive and significant influence on Trust. According to Urban et al. (2009) in their research, showed that website design has a strong and positive effect on online trust. Kim et al. (2009) observed a positive relationship between website design and trust.

Hypothesis 3: Website Design has a positive and significant effect on the Trust.

\subsubsection{Privacy to Trust}

Privacy plays an important role in building consumer trust in online retailers by reducing consumer concerns about misuse of personal data and transaction data vulnerability (Hoffman et al., 1999; Jarvenpaa and Todd, 1997). Sur, S. (2015) stated that privacy has a positive and significant impact on trust. This is also in agreement with the research conducted by Rahimi, M., et al (2012) which revealed that privacy has a positive and significant influence on trust.

Hypothesis 4: Privacy has a positive and significant effect on the Trust

\subsubsection{Fulfillment to Satisfaction}

Collier and Bienstock (2006) say that customers who get services and products in the promised and expected conditions and times will affect the level of satisfaction in electronics. Wolfinbarger and Gilly (2003) in their research stated that Fulfillment itself is the most prominent factor in assessing the level of satisfaction of ecommerce users. Ahmad et al (2017) stated that Fulfillment positively affects Satisfaction.

\section{Hypothesis 5: Fulfillment has a positive and significant effect on the Satisfaction.}

\subsubsection{Responsiveness to Satisfaction}

Responsiveness was also found to have a significant effect on electronic satisfaction (Devaraj et al., 2002). Responsiveness in the research described by Qaemi, V. (2012) as responsive, helpful, and willing service that responds to customer questions quickly has a significant effect on satisfaction. Whereas in a study conducted by Sur, S. (2015) responsiveness has a positive and significant effect on satisfaction.

\section{Hypothesis 6: Responsiveness has a positive and significant effect on the Satisfaction}

\subsubsection{Website Design to Satisfaction}

Urban et al. (2009) showed that website design is closely and positively related to online satisfaction. Kim et al. (2009) observed a positive relationship between website design and satisfaction. Chung and Shin (2010) found that website design directly affects satisfaction while indirectly influences trust and commitment.

\section{Hypothesis 7: Webseite Design has a positive and significant effect on the Satisfaction}

\subsubsection{Privacy to Satisfaction}

From the point of view of relationship quality, security / privacy has been shown to have a positive impact on electronic trust (Casalo et al., 2008; Kim et al., 2009; Rajaobelina et al., 2014), transaction security in an electronic environment has also been shown to be an important predictor of electronic satisfaction. (Szymanski 
and Hise, 2000). Finally, there will be a direct relationship between security and satisfaction, as well as an indirect relationship between security and trust and commitment (Chung and Shin, 2010).

Hypothesis 8: Privacy has a positive and significant effect on the Satisfaction

\subsubsection{Trust to Satisfaction}

In a previous study researched by (Gummerus et al., 2004; Harris and Goode, 2004; Jin and Park, 2006) direct trust was found to have a strong effect on purchase satisfaction. Chou et al (2015) in their research stated that the emergence of Trust was caused by the influence of Satisfaction itself, Research from Ou and Sin (2003) revealed that to strengthen trust from customers in electronic services, companies must first look at customer satisfaction through improving the quality of their services.

\section{Hypothesis 9 : Trust has a positive and significant effect on the Satisfaction}

\subsubsection{Trust to Loyalty}

Choi and Mai (2018) state that trust or trust is a key and important thing in building loyalty or customer loyalty and maintaining a sustainable good relationship with consumers. Furthermore, there is a consensus that occurs between the impact of trust on customer loyalty (Anderson \& Swaminathan, 2011). Harris and Goode (2004) examined the effect of Trust on Loyalty, and showed that there was a positive and significant relationship between Trust and Loyalty.

\section{Hypothesis 10 : Trust has a positive and significant effect on the Loyalty}

\subsubsection{Satisfaction to Loyalty}

Research conducted by Kim (2016) states that there is a relationship between customer satisfaction with customer loyalty. In a study conducted by Teguh Sukoco (2012), it is said that customer satisfaction has a significant effect on customer loyalty, meaning that if customer satisfaction increases, customer loyalty will increase. In addition, research by Saeednia and Valahzaghard (2012) shows that Customer Loyalty and Customer Loyalty have a significant relationship.

Hypothesis 11: Satisfaction has a positive and significant effect on the Loyalty.

\subsection{Research Model}

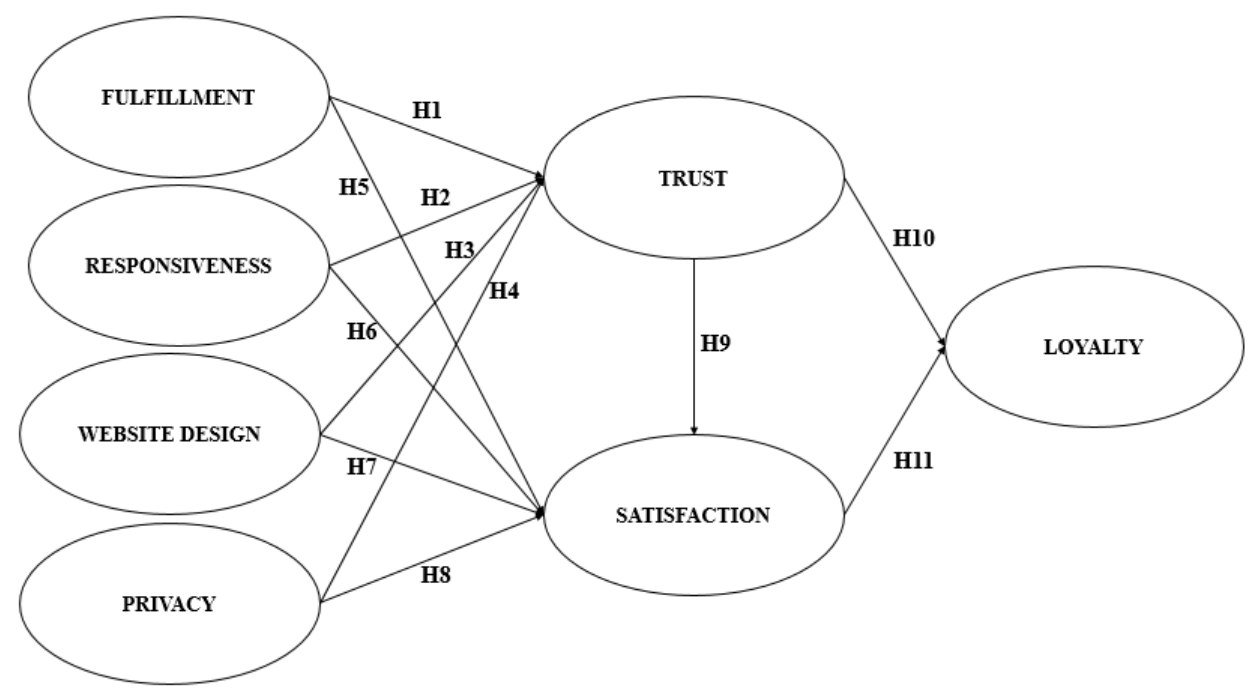

Figure 1. Research Model

\section{RESEARCH METHOD}

This research is causal research, because it is used to develop existing research models to test the research hypotheses that are determined based on literature review to answer the problems identified in the previous chapter. The research method used in this study is a quantitative method, where this method is a scientific approach to managerial and economic decision making. The method used in this study will refer to references that can carry out a simultaneous analysis process associated with a multi-variable research model, the Structural Equation Model (SEM). The program used is the AMOS 22.0 software program. This chapter describes the object of research directed at analyzing models about the relationship between variables to understand the factors that influence loyalty from Tokopedia customers in Surabaya. The sampling method used in this research is nonprobability sampling. This study uses a questionnaire as the main tool in data collection. In this study, researchers will use a purposive sampling technique, where researchers determine respondents who will help researchers to distribute and fill out questionnaires. The area used as a place for distributing questionnaires was the Surabaya 
city, so that respondents were selected according to the criteria determined in this study. The sample used in this research was 110 respondens both male and female respondents, domiciled in Surabaya, with the age range of 18 - 60 years years where the age is an early adulthood (Kotler and Armstrong, 2010). The questionnaire was given to the respondents who had installed Tokopedia apps in the last 6 months and users who have contacted customer service and help centers on the Tokopedia application.

There are 22 indicators used in this study indicators, from the number of existing indicators, the minimum number of samples used is 110-220 respondents, and for this research the number of respondents is 110 people. The sample used for research was 110 respondents. Data collection is done by distributing questionnaires to respondents in accordance with the characteristics of the sample that has been described previously. After completing the questionnaire, the respondent returns the questionnaire that has been filled out and will then be selected by the researcher. The selected questionnaire is a questionnaire that is completely filled out and according to the filling instructions. After selection, the selected questionnaire will be further processed. After the data is tabulated, then the research model will be tested using AMOS software version 22.0. The questionnaire in this study will be divided into two parts. The first part contains questions to get general information about the respondent himself that is useful to determine the suitability of the characteristics of the respondents with the sample criteria. The second part contains questions to obtain research data and analyze the effect of Fulfillment, Responsivness, Website Design, and Privacy on Loyalty through Trust and Satisfaction. The scale used in this study is a Likert Scale, where the answer is provided at intervals from 1=Strongly Disagree (STS) to 5=Strongly Agree (SS). Statements are made using a scale of 1-5 to obtain internal data.

\section{Results and Discussion}

4.1 Assessment of Measurement Model

Table 1 Regression Weights Full Structural Equation Model

\begin{tabular}{|c|c|c|c|c|c|c|c|}
\hline & & & Estimate & S.E. & C.R. & $\mathbf{P}$ & $\begin{array}{c}\text { Std. } \\
\text { Estimate }\end{array}$ \\
\hline Trust & $\begin{array}{l}<-- \\
\end{array}$ & Fullfillment & ,249 & ,208 & 2,193 & ,033 & 0.211 \\
\hline Trust & $\begin{array}{l}<-- \\
\end{array}$ & Responsiveness & ,308 & , 170 & 2,808 & ,021 & 0.306 \\
\hline Trust & $<---$ & Web_Design & ,249 & 290 & 2,858 & ,031 & 0.204 \\
\hline Trust & $\begin{array}{ll}<-- \\
\end{array}$ & Privacy & ,305 & ,238 & 2,286 & ,018 & 0.352 \\
\hline Satisfaction & $\begin{array}{ll}<-- \\
\end{array}$ & Fullfillment & ,504 & ,296 & 2,702 & ,029 & 0.342 \\
\hline Satisfaction & $\begin{array}{l}<-- \\
\end{array}$ & Responsiveness & 182 & ,199 & 1,918 & ,058 & 0.145 \\
\hline Satisfaction & $\begin{array}{l}<-- \\
\end{array}$ & Web_Design & ,388 & ,294 & 2,321 & ,016 & 0.254 \\
\hline Satisfaction & $\begin{array}{l}<-- \\
\end{array}$ & Privacy & ,332 & ,342 & 2,971 & ,032 & 0.306 \\
\hline Satisfaction & $\begin{array}{l}<-- \\
\end{array}$ & Trust & ,331 & ,300 & 2,103 & , 020 & 0.264 \\
\hline Loyalty & $\begin{array}{ll}<-- \\
\end{array}$ & Trust & ,627 & ,313 & 2,005 & ,045 & 0.463 \\
\hline Loyalty & $\begin{array}{l}<-- \\
\end{array}$ & Satisfaction & ,490 & ,228 & 2,147 & ,032 & 0.453 \\
\hline X3 & $\begin{array}{l}<-- \\
\end{array}$ & Fullfillment & 1,000 & & & & 0.437 \\
\hline $\mathrm{X} 2$ & $<---$ & Fullfillment & ,964 & ,329 & 2,928 & ,003 & 0.437 \\
\hline $\mathrm{X} 1$ & $\begin{array}{l}<-- \\
\end{array}$ & Fullfillment & 1,602 & ,627 & 2,558 & ,011 & 0.788 \\
\hline X6 & $\begin{array}{l}<-- \\
\end{array}$ & Responsiveness & 1,000 & & & & 0.566 \\
\hline $\mathrm{X} 5$ & $\begin{array}{l}<-- \\
\end{array}$ & Responsiveness & 1,192 & ,321 & 3,709 & $* * *$ & 0.484 \\
\hline $\mathrm{X} 4$ & $\begin{array}{l}<-- \\
\end{array}$ & Responsiveness & 1,884 & ,515 & 3,659 & $* * *$ & 0.831 \\
\hline X9 & $\begin{array}{l}<-- \\
\end{array}$ & Web_Design & 1,000 & & & & 0.455 \\
\hline $\mathrm{X} 8$ & $\begin{array}{l}<-- \\
\end{array}$ & Web_Design & 1,592 & ,835 & 2,905 & ,037 & 0.63 \\
\hline $\mathrm{X7}$ & $\begin{array}{l}<-- \\
\end{array}$ & Web_Design & 1,192 & ,455 & 2,616 & ,009 & 0.462 \\
\hline $\mathrm{X} 12$ & $\begin{array}{l}<-- \\
\end{array}$ & Privacy & 1,000 & & & & 0.529 \\
\hline X11 & $<---$ & Privacy & ,740 & ,258 & 2,868 & ,004 & 0.422 \\
\hline $\mathrm{X} 10$ & $\begin{array}{l}<-- \\
\end{array}$ & Privacy & 1,390 & ,922 & 2,508 & ,032 & 0.657 \\
\hline Y1 & $\begin{array}{l}<-- \\
\end{array}$ & Trust & 1,000 & & & & 0.453 \\
\hline $\mathrm{Y} 2$ & $\begin{array}{l}<-- \\
\end{array}$ & Trust & 1,623 & 470 & 3,450 & $* * *$ & 0.612 \\
\hline Y3 & $<---$ & Trust & 1,375 & ,397 & 3,463 & $* * *$ & 0.56 \\
\hline Y6 & $\begin{array}{l}<-- \\
\end{array}$ & Satisfaction & 1,000 & & & & 0.62 \\
\hline Y5 & $<---$ & Satisfaction & 1,138 & ,220 & 5,183 & $* * *$ & 0.63 \\
\hline Y4 & $\begin{array}{l}<-- \\
\end{array}$ & Satisfaction & ,847 & ,234 & 3,621 & $* * *$ & 0.415 \\
\hline Y7 & $\begin{array}{l}<-- \\
\end{array}$ & Loyalty & 1,000 & & & & 0.649 \\
\hline Y8 & $\begin{array}{l}<-- \\
\end{array}$ & Loyalty & ,887 & , 171 & 5,179 & $* * *$ & 0.618 \\
\hline
\end{tabular}




\begin{tabular}{|c|c|c|c|c|c|c|c|}
\hline Y9 & $<---$ & Loyalty & 1,014 &, 201 & 5,034 & $* * *$ & 0.597 \\
\hline Y10 & $<---$ & Loyalty &, 974 &, 203 & 4,792 & $* * *$ & 0.557 \\
\hline
\end{tabular}

Source: Amos 22.0 Analysis Result, 2020

C.R. value for each relationship between the variables tested are shown in table 1. The causal relationship that occurs between Fulfillment to Trust, Responsiveness to Trust, Website Design to Trust, Privacy to Trust, Fulfillment to Satisfaction, Website Design to Satisfaction, Privacy to Satisfaction, Trust to Satisfaction, Trust to Loyalty, and Satisfaction to Loyalty have a relationship significant because the CR value is above 2.00.

4.2 Hypotheses Testing

Table 2 Summary of Testing Results

\begin{tabular}{|l|l|}
\hline \multicolumn{1}{|c|}{ Hypothesis } & Analysis \\
\hline $\begin{array}{l}\text { H1: Fulfillment has a significant effect on Trust in Tokopedia's customers } \\
\text { in Surabaya. }\end{array}$ & Accepted \\
\hline $\begin{array}{l}\text { H2: Responsiveness has a significant effect on Trust in Tokopedia's } \\
\text { customers in Surabaya. }\end{array}$ & Accepted \\
\hline $\begin{array}{l}\text { H3: Website Design has a significant effect on Trust in Tokopedia } \\
\text { customers in Surabaya. }\end{array}$ & Accepted \\
\hline $\begin{array}{l}\text { H4: Privacy has a significant effect on Trust in Tokopedia customers in } \\
\text { Surabaya. }\end{array}$ & Accepted \\
\hline $\begin{array}{l}\text { H5: Fulfillment has a significant effect on Satisfaction with Tokopedia } \\
\text { customers in Surabaya. }\end{array}$ & Accepted \\
\hline $\begin{array}{l}\text { H6: Responsiveness does not have a significant effect on Satisfaction with } \\
\text { Tokopedia customers in Surabaya. }\end{array}$ & Reject \\
\hline $\begin{array}{l}\text { H7: Website Design has a significant effect on Satisfaction with } \\
\text { Tokopedia customers in Surabaya. }\end{array}$ & Accepted \\
\hline $\begin{array}{l}\text { H8: Privacy has a significant effect on Satisfaction with Tokopedia } \\
\text { customers in Surabaya. }\end{array}$ & Accepted \\
\hline $\begin{array}{l}\text { H9: Trust has a significant effect on Satisfaction with Tokopedia } \\
\text { customers in Surabaya. }\end{array}$ & Accepted \\
\hline $\begin{array}{l}\text { H10: Trust has a significant effect on Loyalty among Tokopedia customers } \\
\text { in Surabaya. }\end{array}$ & Accepted \\
\hline $\begin{array}{l}\text { H11: Satisfaction has a significant effect on Loyalty among Tokopedia } \\
\text { customers in Surabaya. }\end{array}$ & Accepted \\
\hline
\end{tabular}

Source: Amos 22.0 Analysis Result, 2020

\subsection{Discussion}

\subsubsection{The effect of Fulfillment on Trust}

The estimation parameter between Fulfillment and Trust shows a significant positive result with a value of $\mathrm{CR}=2.193$ and a regression coefficient of 0.211 with an acceptable standard hypothesis, namely CR $\geq \pm 2.00$ with a significance level of $<0.05(5 \%)$, it can be said that hypothesis 1 (H1) is accepted. Fulfillment variable is an important element for customers as a process to improve trust on Tokopedia in Surabaya. From the Fulfillment variable that can be done to improve this variable is to improve the accuracy of customer order status by using a courier provided directly by Tokopedia, resulting in correct and precise delivery accuracy to customers. This can also be accompanied by providing free postage promos to customers who use courier services from Tokopedia directly.

\subsubsection{The effect of Responsiveness on Trust}

The estimation parameter between Responsiveness and Trust shows a significant positive result with a value of $\mathrm{CR}=2.808$ and a regression coefficient of 0.306 with an acceptable standard hypothesis, namely $\mathrm{CR} \geq$ \pm 2.00 with a significance level of $<0.05(5 \%)$, it can be said that hypothesis 2 (H2) is accepted. Responsiveness variable is an important element for customers as a process to improve trust on Tokopedia in Surabaya. From the Responsiveness variable that can be done to improve this variable is improve customer service, or existing help centers to be more responsive to existing questions by summarizing common questions that customers often ask, making it easier for customers to find similar problems. 


\subsubsection{The effect of Website Design on Trust}

The estimation parameter between Website Design and Trust shows a significant positive result with a value of CR $=2.858$ and a regression coefficient of 0.204 with an acceptable standard hypothesis, namely CR $\geq \pm 2.00$ with a significance level of $<0.05(5 \%)$, it can be said that hypothesis 3 (H3) is accepted. Website Design variable is an important element for customers as a process to improve trust on Tokopedia in Surabaya. From the Website Design variable that can be done to improve this variable is to the design of the Tokopedia application, which looks attractive and simple with distinctive and bright colors so that it attracts user's attention visually and seems creative to be used by young people. This needs to be considered and developed by Tokopedia so that Tokopedia customers will also increase with the attractive and creative designs used in the application display.

\subsubsection{The effect of Privacy on Trust}

The estimation parameter between Privacy and Trust shows a significant positive result with a value of CR $=2.286$ and a regression coefficient of 0.352 with an acceptable standard hypothesis, namely $C R \geq \pm 2.00$ with a significance level of $<0.05(5 \%)$, it can be said that hypothesis 4 (H4) is accepted. Privacy variable is an important element for customers as a process to improve trust on Tokopedia in Surabaya. From the Privacy variable that can be done to improve this variable is to To increase the cooperation between Tokopedia and the National Cyber and Crypto Agency (BSSN) so that security is stronger and customer transactions remain safe, in addition Tokopedia can also change passwords or customer passwords to minimize data theft that is rife.

\subsubsection{The effect of Fulfillment on Satisfaction}

The estimation parameter between Fulfillment and Satisfaction shows a significant positive result with a value of $\mathrm{CR}=2.702$ and a regression coefficient of 0.342 with an acceptable standard hypothesis, namely $\mathrm{CR} \geq \pm 2.00$ with a significance level of $<0.05$ (5\%), it can be said that hypothesis 5 (H5) is accepted. Fulfillment variable is an important element for customers as a process to improve Satisfaction on Tokopedia in Surabaya. From the Fulfillment variable that can be done to improve this variable is to be improved by Tokopedia through several available ways, such as promos that are packaged attractively for young people, or service innovations such as faster delivery of goods or free shipping promos for customers who have completed transactions on the Tokopedia application. as much as 2 times a week.

\subsubsection{The effect of Responsiveness on Satisfaction}

The estimation parameter between Responsiveness and Satisfaction shows insignificant results towards positive with a value of $\mathrm{CR}=1.918$ and a regression coefficient of 0.145 with unacceptable standard hypothesis, namely $C R \geq \pm 2.00$ with a significance level of $<0.05(5 \%)$, it can be said that hypothesis 6 (H6) is rejected. Responsiveness variable is an important element for customers as a process to improve Satisfaction on Tokopedia in Surabaya. This explains that Tokopedia has prepared good facilities to respond to all complaints and questions asked from customers. It turns out that what Tokopedia has done has not been able to make customers feel satisfied, but customers already feel that Tokopedia is always fast in responding to customer needs, this is because the age of the sample who is the respondent in this study is the majority of 18-35 years, where respondents are in the age range like this, they are less concerned with fast responses when they receive problems that occur when using the Tokopedia application. This is also because the age range of respondents, including 18-35 years, is a technology literate generation, so that they can solve their own problems when there is a problem with the transaction process being carried out. Tokopedia also always provides fast responses to customer questions through the Tokopedia help center feature, Tokopedia is able to resolve customer complaints well through the help center feature. In the future, Tokopedia can further improve complaint services and respond quickly when users encounter several obstacles and problems so that users can feel satisfied with what Tokopedia is doing.

\subsubsection{The effect of Website Design on Satisfaction}

The estimation parameter between Website Design and Satisfaction shows a significant positive result with a value of $\mathrm{CR}=2.321$ and a regression coefficient of 0.254 with an acceptable standard hypothesis, namely $\mathrm{CR} \geq \pm 2.00$ with a significance level of $<0.05(5 \%)$, it can be said that hypothesis 7 (H7) is accepted. Website Design variable is an important element for customers as a process to improve Satisfaction on Tokopedia in Surabaya. From the Website Design variable that can be done to improve this variable is improved by updating the existing display on Tokopedia for certain events such as Valentine's Day, the initial appearance which is usually green and white combined with pink which is identical to Valentine's Day, and making a display of chocolate promos or other gifts on the main page. in order to make it easier for customers, so that customers feel satisfied using Tokopedia. 


\subsubsection{The effect of Privacy on Satisfaction}

The estimated parameter between Privacy and Satisfaction shows a significant positive result with a value of CR = 2.971 and a regression coefficient of 0.306 with an acceptable standard hypothesis, namely $\mathrm{CR} \geq \pm 2.00$ with a significance level of $<0.05(5 \%)$, it can be said that hypothesis 8 (H8) is accepted. Privacy variable is an important element for customers as a process to improve Satisfaction on Tokopedia in Surabaya. From the Privacy variable that can be done to improve this variable is increased by using an adequate security system such as a numerlock or configuration used to access personal data by customers in the customer's store profile. Or you can also use personal questions that are only known by the customer when the customer logs in to the application, such as the name of the parent or the name of the teacher who was asked when creating the account for the first time, in this way the customer will be satisfied with the services provided by Tokopedia towards its customers.

\subsubsection{The effect of Trust on Satisfaction}

The estimation parameter between Trust and Satisfaction shows a significant positive result with a value of CR = 2.103 and a regression coefficient of 0.264 with an acceptable standard hypothesis, namely $\mathrm{CR} \geq \pm 2.00$ with a significance level of $<0.05$ (5\%), it can be said that hypothesis 9 (H9) is accepted. Trust variable is an important element for customers as a process to improve Satisfaction on Tokopedia in Surabaya. From the Trust variable that can be done to improve this variable is can be improved by fulfilling what Tokopedia has promised to customers who make transactions, such as free shipping for purchases over five hundred thousand. Or a discount with the minimum number of purchases that has been determined by Tokopedia, they must fulfill this so that customers are satisfied with the services from Tokopedia.

\subsubsection{The effect of Trust on Loyalty}

The estimation parameter between Trust and Loyalty shows a significant positive result with a value of CR $=2.005$ and a regression coefficient of 0.463 with an acceptable standard hypothesis, namely $C R \geq \pm 2.00$ with a significance level of $<0.05(5 \%)$, it can be said that hypothesis 10 (H10 is accepted. Trust variable is an important element for customers as a process to improve Loyalty on Tokopedia in Surabaya. From the Trust variable that can be done to improve this variable is can be achieved through an open process for customer transactions with Tokopedia. For example, such as confirmation of payments by Tokopedia for customers, updates on delivery of goods ordered by customers and fulfillment of promos that have been promised by Tokopedia to customers, can also make customers believe what Tokopedia promises so customers will continue to use Tokopedia and invite others to use Tokopedia. Tokopedia can also see what is the trend, and carry out a short-term strategy for planning existing trends, to make customers satisfied. One way to do this is to invite customers to participate in new services offered by Tokopedia, such as mutual fund investment services in the Tokopedia application.

\subsubsection{The effect of Satisfaction on Loyalty}

The estimation parameter between Satisfaction and Loyalty shows a significant positive result with a value of $\mathrm{CR}=2.147$ and a regression coefficient of 0.453 with an acceptable standard hypothesis, namely CR $\geq$ \pm 2.00 with a significance level of $<0.05(5 \%)$, it can be said that hypothesis 11 (H11) is accepted. Satisfaction variable is an important element for customers as a process to improve Loyalty on Tokopedia in Surabaya. From the Satisfaction variable that can be done to improve this variable is to providing shopping discount promos for certain events, making existing service innovations, as well as experiencing easy application use offered by Tokopedia. Tokopedia can also make customers feel satisfied with the services provided when they use the Tokopedia application so that when they make transactions by making innovations in the application display, because considering that the majority of respondents in this study are those aged 18-35 years who are concerned about display at the time of use of the application to increase customer satisfaction.

\section{Conclusion}

5.1 Managerial Implications

Tabel 2 Managerial Implications

\begin{tabular}{|l|c|}
\hline \multicolumn{1}{|c|}{ Current Research } & Managerial Implications \\
\hline $\begin{array}{l}\text { Fulfillment is one element that has an } \\
\text { influence in the process of increasing }\end{array}$ & $\bullet \quad \begin{array}{l}\text { Tokopedia can maintain what has been done so far } \\
\text { and improve its services again through existing } \\
\text { Trust and Satisfaction. }\end{array}$ \\
$\begin{array}{l}\text { features to confirm customer payments quickly, this } \\
\text { can be done by improving the quality of existing } \\
\text { human resources such as training for programmers }\end{array}$ \\
\hline
\end{tabular}




\begin{tabular}{|c|c|}
\hline & $\begin{array}{l}\text { who are responsible for the jobdesk, in order to } \\
\text { increase speed the service } \\
\text { Tokopedia can maintain an accurate display of the } \\
\text { user's order status by working with third parties or } \\
\text { existing couriers to improve the tracking system so } \\
\text { that users can always see the details of their order } \\
\text { where they are and know clear information from the } \\
\text { courier sending. } \\
\text { Tokopedia can make its own courier to distribute } \\
\text { existing goods so that the system can be combined } \\
\text { with existing services so that customers are more } \\
\text { interested in using Tokopedia, and lastly, Tokopedia } \\
\text { can maintain transparency in providing promos, such } \\
\text { as users can find out about discounts when promos } \\
\text { are used }\end{array}$ \\
\hline $\begin{array}{l}\text { Responsiveness is one element that has } \\
\text { an influence in the process of } \\
\text { increasing Trust and Satisfaction. }\end{array}$ & $\begin{array}{l}\text { - Tokopedia can add additional features such as 24- } \\
\text { hour communication services to respond to existing } \\
\text { customer needs such as system disruptions or other } \\
\text { things. } \\
\text { Tokopedia can also improve its existing human } \\
\text { resources to respond to customer questions that } \\
\text { cannot be resolved by themselves, by providing } \\
\text { training on how to solve different types of problems } \\
\text { for each customer. } \\
\text { Tokopedia can add a feature in the form of a } \\
\text { summary of questions that customers often ask when } \\
\text { they have problems such as "logging in to the } \\
\text { application cannot be done", "what is the payment } \\
\text { method via ATM". This can be done so that customer } \\
\text { complaints can be resolved quickly and well. }\end{array}$ \\
\hline $\begin{array}{l}\text { Website Design is one element that has } \\
\text { an influence in the process of } \\
\text { increasing Trust and Satisfaction. }\end{array}$ & $\begin{array}{l}\text { - Tokopedia can do some things like focus on critical } \\
\text { information such as information promo flash sale, } \\
\text { free delivery cost, or promo use an existing business } \\
\text { partner as promo discounted using a credit card BNI } \\
\text { bank and others. } \\
\text { Tokopedia can maintain what was already there in } \\
\text { terms of the appearance of the existing application, } \\
\text { but this can also be improved through updating the } \\
\text { existing appearance of the application such as } \\
\text { display images or logos, bright color combinations } \\
\text { and animations or sounds that can be combined on } \\
\text { the start page when the customer uses the Tokopedia } \\
\text { application. } \\
\text { Tokopedia can make the appearance of the } \\
\text { application more attractive by adding animation to } \\
\text { the existing icon to attract attention, such as a unique } \\
\text { shape and has a striking color but not excessive } \\
\text { because it can make the appearance of the } \\
\text { application attractive when used by users. }\end{array}$ \\
\hline $\begin{array}{l}\text { Privacy is one element that has an } \\
\text { influence in the process of increasing } \\
\text { Trust and Satisfaction. }\end{array}$ & $\begin{array}{l}\text { - Tokopedia can make improvements through the } \\
\text { form of security layers used by Tokopedia, such as } \\
\text { the use of the Confidentiality Aspect of } \\
\text { confidentiality which guarantees that data cannot be } \\
\text { intercepted by unauthorized parties. } \\
\text { Tokopedia can provide a feature where, if the user } \\
\text { does not access the application for one week, when } \\
\text { the customer will reuse the application, there will be } \\
\text { questions regarding the verification of the customer's } \\
\text { personal data such as the question for the name of }\end{array}$ \\
\hline
\end{tabular}




\begin{tabular}{|c|c|}
\hline & $\begin{array}{l}\text { the mother, father, or sibling that was prepared } \\
\text { beforehand when the customer created an account on } \\
\text { first time using the Tokopedia application. } \\
\text { Tokopedia can increase the feeling of security for } \\
\text { customers who will make transactions by } \\
\text { collaborating with existing banks and working with } \\
\text { the National Cyber and Crypto Agency (BSSN) so } \\
\text { that security is stronger and customer transactions } \\
\text { remain safe. }\end{array}$ \\
\hline $\begin{array}{l}\text { Trust is one element that has an } \\
\text { influence in the process of increasing } \\
\text { Satisfaction and Loyalty. }\end{array}$ & $\begin{array}{l}\text { - Tokopedia has done this well, but it can also be } \\
\text { improved by providing scheduled updates for every } \\
\text { user using the Tokopedia application. } \\
\text { Tokopedia can change the user's account password } \\
\text { when it hasn't been used for a long time, of course, } \\
\text { with the consent of the existing user. } \\
\text { Tokopedia can hear input from customers when a } \\
\text { customer provides input such as input regarding the } \\
\text { application display, payment methods, delivery } \\
\text { methods, and so on. } \\
\text { Tokopedia can make an appeal for users to be more } \\
\text { careful and careful about transaction actions outside } \\
\text { the Tokopedia application, such as preventing direct } \\
\text { transfers to private accounts outside of Tokopedia. } \\
\text { So that in the end users are not easy to be harmed. }\end{array}$ \\
\hline $\begin{array}{l}\text { Satisfaction is one element that has an } \\
\text { influence in the process of increasing } \\
\text { Loyalty. }\end{array}$ & $\begin{array}{l}\text { - Tokopedia needs to maintain what has been done to } \\
\text { make customers satisfied with the services provided, } \\
\text { such as a help center service, an attractive } \\
\text { appearance, and an active call center to help. } \\
\text { Tokopedia can add various existing features to make } \\
\text { the customer's shopping experience even better than } \\
\text { before, such as small games while waiting for } \\
\text { payment confirmation, or animation added when } \\
\text { customers use Tokopedia on certain days, such as } \\
\text { Christmas, Eid and others . } \\
\text { Tokopedia can improve the quality of products sold } \\
\text { with existing standards, this is consistently done so } \\
\text { that users are satisfied and get what they are looking } \\
\text { for and need in the Tokopedia application. }\end{array}$ \\
\hline
\end{tabular}

This study provides evidence that the Fulfillment significantly affected Trust, Responsivness significantly affected Trust, Website Design significantly affected Trust, Privacy significantly affected Trust, Fulfillment significantly affected Satisfaction, Website Design significantly affected Satisfaction, Privacy significantly affected Satisfaction,Trust significantly affected Satisfaction, Trust significantly affected Loyalty, and Satisfaction significantly affected Loyalty.

\subsection{Recommendation}

Seeing the results of existing research where there are still many limitations on research by the author, the recommendations could be submitted by the authors are as follows:

1. Seeing the limitations regarding the object of research that only takes respondents, namely Tokopedia customers in Surabaya, it is hoped that the next research using the same or modified model can be applied to different objects to get more general results on the factors that affect loyalty.

2. Further research is expected to complement the existing variables in this research so that it can further enhance the understanding of the factors that affect Loyalty where these variables include Brand Image, Functional Value, Product Quality, and Behavioral Intention.

3. Further research can be developed by connecting the factors that affect loyalty based on income levels. Future research could also expand the scope of respondents to be researched, or carry out their research 
in a different area from the current research. So that further research carried out increasingly provides a broad picture of Loyalty.

In addition, it is also expected to be able to use the Structural Equational Model (SEM) but by using the Lisrel software in further research. 


\section{REFERENCES}

Ahmad, A., Rahman, O., \& Khan, M. N. (2017). Exploring the role of website quality and hedonism in the formation of e-satisfaction and e-loyalty. Journal of Research in Interactive Marketing.

Al-dweeri, R. M., Obeidat, Z. M., Al-dwiry, M. A., Alshurideh, M. T., \& Alhorani, A. M. (2017). The impact of e-service quality and e-loyalty on online shopping: moderating effect of e-satisfaction and etrust. International Journal of Marketing Studies, 9(2), 92-103.

Amin, M., Rezaei, S., \& Abolghasemi, M. (2014). User satisfaction with mobile websites: the impact of perceived usefulness (PU), perceived ease of use (PEOU) and trust. Nankai Business Review International.

Arcand, M., PromTep, S., Brun, I., \& Rajaobelina, L. (2017). Mobile banking service quality and customer relationships. International Journal of Bank Marketing.

Bakti, D. K. (2013). STUDI INDIGENOUS TRUST TO LEADER PADA KARYAWAN JAWA (Doctoral dissertation, Universitas Negeri Semarang).

Bose, S., \& Rao, V. G. (2011). PERCEIVED BENEFITS OF CUSTOMER LOYALTY PROGRAMS: VALIDATING THE SCALE IN THE INDIAN CONTEXT. Management \& Marketing, 6(4).

Burgoon, J., Parrott, R., LePoire, B., Kelley, D., Walther, J. and Perry, D. (1989), “Maintaining and restoring privacy through communication in different types of relationship', Journal of Social and Personal Relationships, Vol. 6, pp. 131-58.

Cohen, S., Eppley, G. L., Purdy, D. M., Johnson, J. E., Millet, S. J., Swartz, S. T., ... \& Rjagopalan, A. (2009). U.S. Patent No. 7,512,957. Washington, DC: U.S. Patent and Trademark Office.

David, R Fred. (2012). Strategic Management Concepts \& Cases. Pearson Academic; 14th edition

De Cew, J. (2006). "Privacy in Zalta, E.N. (Ed.).Standford Encyclopedia of Philosophy, Standford University, Standford, CA.

Fernandes, F. A. P. (2017). Perceived value of buying tourism services through an Online Travel Agency.

Gefen, D., Karahana, E., \& Straub, D. W.,. (2003). Trust and Tam in Online Shopping : An Integrated Model. MIS Quarterly, Vol. 27, No.1, 51-90.

Giovanis, A. N., \& Athanasopoulou, P. (2014). Gaining customer loyalty in the e-tailing marketplace: the role of e-service quality, e-satisfaction and e-trust. International Journal of Technology Marketing 6, 9(3), 288304.

Han, H., \& Ryu, K. (2009). The roles of the physical environment, price perception, and customer satisfaction in determining customer loyalty in the restaurant industry. Journal of hospitality \& tourism research, 33(4), 487-510.

Hellier, P.K., Geursen, G.M., Carr, R.A. and Rickard, J.A. (2003). “Customer Repurchase Intention: A General Structural Equation Model". 
Holloway, B. B., \& Beatty, S. E. (2008). Satisfiers and dissatisfiers in the online environment: A critical incident assessment. Journal of service research, 10(4), 347-364.

Kassim, N., \& Abdullah, N. A. (2010). The effect of perceived service quality dimensions on customer satisfaction, trust, and loyalty in e-commerce settings. Asia pacific journal of marketing and logistics.

Katz, Bernardt (1994). “Komunikasi Bisnis”. Cetakan Pertama, Jakarta: Penerbit Ikrar Mandiri Abadi.

Kim, J. H., Kim, C.,. (2010). E-service quality perceptions: a cross-cultural comparison of American and Korean Consumers. Journal of Research in Interactive Marketing, 257-275.

Kim, J., Jin, B., \& Swinney, J. L. (2009). The role of etail quality, e-satisfaction and e-trust in online loyalty development process. Journal of retailing and Consumer services, 16(4), 239-247.

Kotler, P., \& Keller, K. L. (2009). Manajemen Pemasaran, Edisi 13. Jakarta: Erlangga, 14.

Kotler, Phillip dan Gary Amstrong. (2008). Prinsip-prinsip Pemasaran, jilid 2, edisi 8. Jakarta: Penerbit Erlangga.

Kotler, Phillip. (2005). "Manajemen Pemasaran: Analisis, Perencanaan, Implementasi, dan Kontrol Edisi Kesebelas". Alih Bahasa, Hendra Teguh. Jakarta : PT. Prenhallindo.

Kusdyah, I. (2012). P (Studi Kasus Erha Clinic Surabaya). Jurnal Manajemen Pemasaran, 7(1), $25-32$.

Li, H., Aham-Anyanwu, N., Tevrizci, C., \& Luo, X. (2015). The interplay between value and service quality experience: e-loyalty development process through the eTailQ scale and value perception. Electronic Commerce Research, 15(4), 585-615.

Malhotra, N.K., KIM, S.S., and Agarwel, J. (2004) “internet users' Information Privacy Concern (IUIPC). The construct, the scale, and a causal model". Information system research 15 (4), 336-355.

Moriuchi, E., \& Takahashi, I. (2016). Satisfaction trust and loyalty of repeat online consumer within the Japanese online supermarket trade. Australasian Marketing Journal (AMJ), 24(2), 146-156.

Ndubisi, N. O., dan Jantan, M. (2003). "Evaluating IS usage in Malaysian small and medium-sized firms using the technology acceptance model". Logistics Information Management Vol. 16 , 440-450.

Ojha, A., \& Gupta, M. P. (2007). Does E-Governance Enhance Trust in Government?. In Proceedings of 5th International Conference on E-Governance, Hyderabad, India. doi (Vol. 10, No. 1.105, p. 3708).

Parasuraman, A., Zeithaml, V. A., \& Malhotra, A. (2005). ES-QUAL: A multiple-item scale for assessing electronic service quality. Journal of service research, 7(3), 213-233.

Parasuraman, A., Zeithaml, V. A., \& Malhotra, A. (2005). ES-QUAL: A multiple-item scale for assessing electronic service quality. Journal of service research, 7(3), 213-233

Qaemi, V. (2012). Surveying the impact of satisfaction and e-reliability on customers' loyalty in e-purchase process: a case in Pars Khodro co. Management Science Letters, 2(6), 2103-2112. 
Rahimi, M., Bidmeshk, O. G., \& Mirzaalian, F. (2012). A proposed model of customer e-loyalty measurement in internet banking. Life Science Journal, 9(4), 2457-2462.

Rahmadhany, M. Dinamika Trust Terhadap Pasangan Pada Perempuan Setelah Melakukan Aborsi.

Rai, A. K., \& Medha, S. (2013). The antecedents of customer loyalty: An empirical investigation in life insurance context. Journal of Competitiveness, 5(2), 139-163.

Reswick, J.B. (1965). “Pengertian Design dan Design interior”. Amerika Serikat.

Rian Pramono.(2012).“Analisis Pengaruh Harga Kompetitif, Desain Produk, dan layanan Purna Jual Terhadap Minat Beli Konsumen Sepeda Motor Yamaha (Studi Kasus Pada Masyarakat Kota Semarang).”

Rofiq, A. (2007). Pengaruh dimensi kepercayaan (trust) terhadap partisipasi pelanggan E-commerce. Universitas Brawijaya Malang.

Rosenberg, L. \& Czepiel, J. (1983), “A Marketing Approach for Consumer Retention. Journal of Consumer Marketing 1", hal 45-51.

Rosner Klimchuk, M., \& Krasovec, S. A. (2006). Packaging Design: Successful Product Branding from Concept to Shelf. John Siley to Sons.

Sahadev, S., \& Purani, K. (2008). Modelling the consequences of e-service quality. Marketing Intelligence \& Planning.

Sahadev, S., \& Purani, K. (2008). Modelling the consequences of e-service quality. Marketing Intelligence \& Planning, 26(6), 605-620. doi:10.1108/02634500810902857 .

Sahadev, S., \& Purani, K. (2008). Modelling the consequences of e-service quality. Marketing Intelligence \& Planning.

Samar, R., Norjaya, M.Y. dan Feras, M.A. (2017). "Mengukur Peran Desain Situs Web, Jaminan, Layanan Pelanggan dan Citra Merek Terhadap Loyalitas Pelanggan dan Niat Untuk Mengadopsi Internet Banking".

Santouridis, I., Trivellas, P., \& Tsimonis, G. (2012). Using E-S-QUAL to measure internet service quality of ecommerce websites in Greece. International Journal of Quality and Service Sciences 4(1), 86-98.

Santouridis, ilias, dkk (2012). "Investigating the impact of service quality and customer satisfaction on customer loyalty in mobile telephony in greece.” The TQM Jurnal. Vol 22 No 3, 2010 Hal 330-343.

Singh, J., Sirdeshmukh, D.,. (2000). Agency and trust mechanisms in consumer satisfaction and loyalty judgments. Journal of the Academy of Marketing Science 28(1), 150-167.

Sur, S. (2015). The role of online trust and satisfaction in building loyalty towards online retailers: Differences between heavy and light shopper groups. In LISS 2014 (pp. 489-494). Springer, Berlin, Heidelberg.

Sutisna. (2001). "Perilaku Konsumen dan Komunikasi Pemasaran. PT. Remaja Rosdakarya, Bandung."

Tjiptono, F. (2008). Service management mewujudkan layanan prima. Yogyakarta: Andi. 
Tunggal, Amin Widjaja. (2014). "Internal Audit, Enterprise Risk Management \& Corporate Governance." Jakarta: Harvarindo.

Vakulenko, Y., Shams, P., Hellström, D., \& Hjort, K. (2019). Online retail experience and customer satisfaction: the mediating role of last mile delivery. The International Review of Retail, Distribution and Consumer Research, 29(3), 306-320.

Valerie, P. A. (2001). Delivering Quality Service.(diterjemahkan oleh sutanto).

Venkatesh et al. (2003). “User Acceptance of Information Technology : Toward a Unified View,” MIS Quarterly., vol. 27 , no. $3,2003$.

Wolfinbarger, M., \& Gilly, M. C. (2003). eTailQ: dimensionalizing, measuring and predicting etail quality. (2003). eTailQ: dimensionalizing, measuring and predicting etail quality. Journal of retailing, 79(3), 183198.

Yang, Z. \& Fang, X. (2004). Online Service Quality dimensions and their relationships with Satisfaction a content analysis of customer reviews of securities brokerage services. International Journal of Service Industry Management, Vol. 15., No. 3., 302-26.

Zeithaml, V.A., Bitner, M.J., \& Gremler, D.D. (2013). Services Marketing - Integrating Customer Focus Across the Firm. Singapore: McGraw-Hill, Inc. International Edition.

Zeithaml, Valarie A and Mary Jo Bitner. (2009). Service Marketing. Singapore: McGraw-Hill Companies, Inc.:3287.

Ziaullah, M., Yi, F., \& Akhter, S. N. (2014). E-loyalty: The influence of product quality and delivery services on e-trust and e-satisfaction in China. International Journal of Advancements in Research \& Technology, 3(10), 2031.

\section{APPENDIX}

TABLE: The Items List Used in the study

Fulfillment

X1: Tokopedia confirmed my payment quickly.

$\mathrm{X} 2$ : Tokopedia displays my order status accurately.

$\mathrm{X} 3$ : Tokopedia has kept its service promise in providing promos. Responsiveness

$\mathrm{X} 4$ : Tokopedia is always fast in responding to customer needs.

X5: Tokopedia always responds quickly to customer questions through the Tokopedia help center feature.

X6: Tokopedia is able to resolve customer complaints well through the help center feature.

X7: Tokopedia has an attractive application design

$\mathrm{X} 8$ : Tokopedia provides complete information.

X9: Tokpedia has an application design that helps simplify the transaction process.

X10: I feel that Tokopedia has adequate security features.

X11: I feel safe in my transactions with Tokopedia.

$\mathrm{X} 12$ : I feel my privacy is protected on Tokopedia. 


\section{Trust}

Y1: I trust the information provided by Tokopedia.

Y2: I feel that Tokopedia is reliable.

Y3: I believe Tokopedia will always prioritize customer needs.

\section{Satisfaction}

Y4: I am satisfied with the products offered by Tokopedia.

Y5: Overall I am satisfied with Tokopedia.

Y6: I am satisfied with my shopping experience at Tokopedia.

$$
\text { Loyalty }
$$

Y7: Tokpedia is my first choice in online shopping.

Y8: I plan to shop again at Tokopedia at a later date.

Y9: I would recommend Tokopedia to others.

Y10: I will not switch to applications other than Tokopedia. 